\title{
試料水平型パルス中性子反射率計
}

鳥飼 直也

(三重大学 大学院工学研究科)

\section{Pulsed-neutron Reflectometers with a Horizontal Sample Geometry}

Naoya Torikai

Department of Chemistry for Materials, Mie University

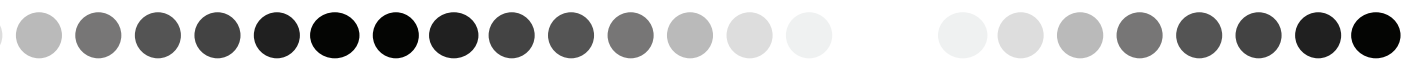

Keywords : CRISP, SURF，SPEAR，試料水平型パルス中性子反射率計

1.はじめに

中性子反射率法は，中性子が物質の界面で示寸 光学的な反射現象を利用して，一般に観察が難し い極薄な物質の表面・界面や薄膜の構造をサブ $\mathrm{nm}$ スケールの高い空間分解能でかつ非破壊で調心゙ら れる，物質界面の研究に極めて有力な測定手法で ある[1-4]. 中性子反射率計は, 装置コンポーネン トの構成がシンプルで，かつ比較的安価であるこ とから，原子炉，パルス中性子源に拘らず，多く の実験施設で複数台の反射率計が設置され物質界 面研究に利用されている.

反射率計は, 装置上での試料の置き方により垂 直型と水平型に大別される。気/液や液/液界面 のような自由界面は垂直に立てられないことから， その測定は試料水平型の装置に限られるが，それ 以外はどちらのタイプの反射率計でも測定できる. 水平型の装置では, 水平に保持した試料に中性子 を斜入射させるために下方にビームを取出す必要 があり，ビームライン設計にやや難しさがある.

ここでは，筆者がこれまでに利用した英国 ISIS と米国 LANSCE の試料水平型パルス中性子反射 率計について簡単に紹介する.

\section{2. 英国 ISIS の反射率計}

筆者が主に訪れた 2000 年前後には，まだ J-PARC や SNS は立ち上がっておらず, 当時, 加 速器出力が $160 \mathrm{~kW}$ の ISIS はパルス中性子源では 世界最強であった. 単純に加速器出力で比べると KENS（3 kW）と 50 倍もの強度差があり, 当然で はあるが，初めて ISIS で実験を行った時に試料の アライメントが非常に短い時間で済むことに感銘 を受けた。 その当時の ISIS には，1980 年代前半 に中性子反射率法による物質界面研究の先駆けと なった CRISP[5] と, 1990 年代半ばに立ち上げられ 基本的な設計思想は踏襲しているが CRISP より も入射ビーム強度が増強された SURF[6]の 2 台の 試料水平型の反射率計が稼働していた.
CRISP 及び SURF では，液体水素モデレータか らの白色中性子が水平より 1.5 度下向きに取出さ れている。 どちらのビームラインも試料がモデレ 一タを直接見込む形で中性子が導かれているため, 中性子発生の瞬間に生じる高エネルギー中性子に 由来するバックグラウンドの軽減に T0 チョッパ 一が用いられている. 加速器の運転周期 $(50 \mathrm{~Hz})$ と装置の全長から，測定には波長範囲が 0.05-0.65 $\mathrm{nm}$ の白色中性子が定常的に用いられる. CRISP と SURF の違いは, CRISP には中性子偏極デバイ スが備えられ偏極中性子による反射率測定が可能 なのに対し，SURF では集束ミラーにより高い入 射ビーム強度が得られることから短時間での時分 割測定が優先的に行われる. Fig.1 に, SURF 反射 率計の試料台周辺の写真を示す。自由界面を有す る試料に周囲から振動が伝わるのを防ぐために, 実験室の床面から独立して据えられたコンクリー トブロックの上に, アクティブ除振台を設置し, その上に液体トラフ等の試料が置かれる. 検出器

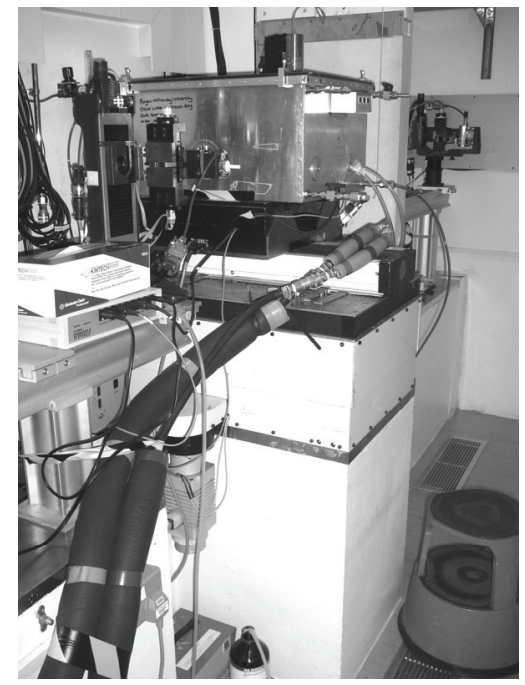

Fig.1 A photograph of a sample stage of SURF, taken from downstream of the beamline. A large box for a liquid trough is mounted on it. 
については，鏡面反射だけを測定する場合には ${ }^{3} \mathrm{He}$ 比例計数管，非鏡面反射の観測には位置敏感 型検出器 (CRISP : ${ }^{3} \mathrm{He}$ 一次元 PSPC, SURF : ZnS 二次元シンチレーション検出器）が使われる.

Fig.2にSURFの二台の検出器架台をビームライン の上流側から撮影した写真を示す。手前側が ${ }^{3} \mathrm{He}$ 比例計数管を支えている架台である．鏡面反射率 測定では，複数の異なる入射角で得られた反射率 曲線を継ぎ足すことで広い $q$ 領域がカバーされる。 しかし，自由界面の測定では，試料自身を傾ける ことが出来ないために，スーパーミラーによる反 射を利用して 1.5 度より小さな角度の下方ビーム を作り測定が行われる. Fig.3 には CRISP で一次 元 PSD を用いて测定したブロック共重合体薄膜 $[3,7]$ からの反射強度の二次元マップを示す.この ように白色中性子に一次元 PSD を組合わせるこ とで，鏡面反射と非鏡面反射の同時計測が可能で ある。

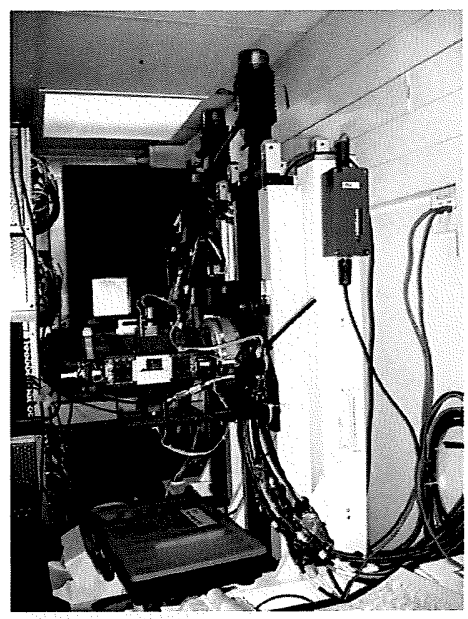

Fig.2 A photograph of two detector towers of SURF, taken from upstream of the beamline.

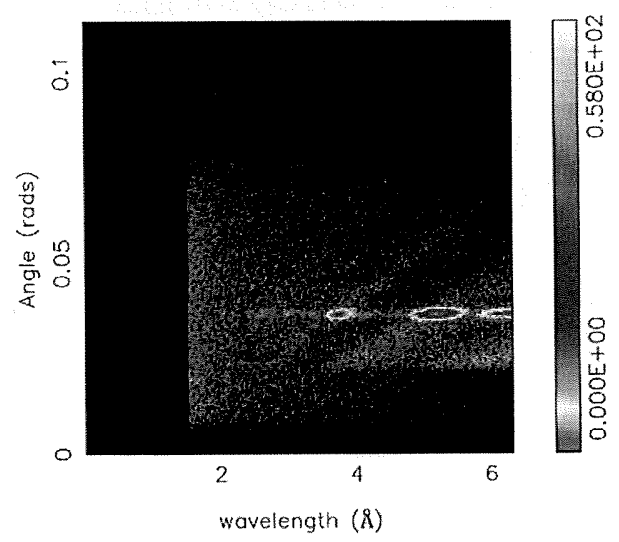

Fig.3 A two-dimensional map of the reflected neutron intensity from a block copolymer thin film forming an alternating lamellar structure.

試料環境装置としては, 各種液体トラフ, 高温 セル等の他に，CRISPには電磁石が用意されてい る. 定常的な測定については，試料ステージに複 数の試料を一度にセットし, 自動測定が行われる.

現在，ISIS には第 2 ターゲットステーションが
立ち上がり，CRISP，SURF の他に，いずれも試 料水平型で，ロングパルスの中性子を利用したそ れぞれに特徴を持つ 3 台の反射率計（INTER， POLREF, OFFSPEC) [8]が稼働している.

\section{3. 米国 LANSCE の反射率計}

LANSCE (加速器出力 $80 \mathrm{~kW}$ )については, KENS のシャットダウン (2006 年 3 月) 後, 海外プロジ エクトとして，試料水平型の SPEAR 反射率計 [9] を利用する機会を得た. SPEAR も最初の立ち上げ は 1980 年代後半と歴史が古く, その後ビームライ ン設計の変更を経て，現在は液体水素モデレータ から水平より下方に 0.9 度の角度で試料がモデレ 一夕を直接見込む形でビームが導かれている，高 エネルギー中性子の軽減には T0 チョッパーが用 いられている. 加速器の運転周期が $20 \mathrm{~Hz}$ のため, ISISの反射率計より波長の長い 0.45-1.6 nmの中性 子が定常的に使われる.検出器は ${ }^{3} \mathrm{He}$ 一次元 PSPC が標準で，試料と検出器の閒にはバックグラウン ド軽減のために真空パスが検出器の上下動に連動 するように設置されている.自由界面の測定では, 作り出せる下方ビーム角度の制約により，0.7 $\mathrm{nm}^{-1}$ と比較的狭い $q$ 範囲に限られている.

参考文献

[1]入門講座「中性子反射率測定」(0)-(8)，波紋 18， 220 (2008); 18, 221 (2008); 19, 34 (2009); 19, 101 (2009); 19, 105 (2009); 19, 161 (2009); 19, 165 (2009); 19, 234 (2009); 19, 238 (2009).

[2]鳥飼直也, RADIOISOTOPES 59, 693 (2010).

[3] N. Torikai et al., Polym. J. 39, 1238 (2007).

[4] N. Torikai, In Neutrons in Soft Matter; T. Imae, T. Kanaya, M. Furusaka, N. Torikai, Eds.; John Wiley \& Sons, Inc.: New Jersey, 2011; p 115.

[5] J. Penfold and R. K. Thomas, J. Phys: Condens. Matter 2, 1369 (1990).

[6] J. Penfold et al., J. Chem. Soc., Faraday Trans. 93, 3899 (1997).

[7] N. Torikai et al., Physica B 283, 12 (2000).

[8] J. R. P. Webster et al., Eur. Phys. J. Plus 126, 112 (2011).

[9] M. Dubey et al., Eur. Phys. J. Plus 126, 110 (2011). 